\title{
Differential effect of biotin on carboxylase activity and mice skeletal muscle metabolism*
}

\author{
Marco Antonio Parra Montes de Oca ${ }^{1}$, Gabriel Gutiérrez-Ospina ${ }^{1}$, Pablo Hofmann Salcedo ${ }^{1}$, \\ Alma Lilia Fuentes-Farías ${ }^{2}$, Esperanza Meléndez-Herrera² ${ }^{2}$ Margarita Gómez-Chavarín ${ }^{1}$, \\ Armida Báez-Saldaña ${ }^{1 \#}$ \\ ${ }^{1}$ Departamento de Biología Celular y Fisiología, Instituto de Investigaciones Biomédicas, Universidad Nacional Autónoma de \\ México, Ciudad Universitaria, D. F. México \\ ${ }^{2}$ Laboratorio de Eco-fisiología Animal, Instituto de Investigaciones sobre los Recursos Naturales, Universidad Michoacana de San \\ Nicolás de Hidalgo, Morelia, México \\ Email:
}

Received 30 May 2013; revised 30 June 2013; accepted 10 July 2013

Copyright (C) 2013 Marco Antonio Parra Montes de Oca et al. This is an open access article distributed under the Creative Commons Attribution License, which permits unrestricted use, distribution, and reproduction in any medium, provided the original work is properly cited.

\section{ABSTRACT}

In mammalian skeletal muscle there are four carboxylases involved in several biochemical processes like gluconeogenesis, tricarboxylic acid cycle anaplerosis, metabolism of fatty acids and metabolism of various amino acids. It has been shown that biotin deficiency reduces body weight at the expense of muscular mass. When necessary, the liver uses skeletal muscle protein to provide glucose and amino acids to organs in need of such compounds. In this paper we analyzed carboxylase specific activities in hind limb skeletal muscle of 3 weeks old BALB/c male mice, at 0 , $1,4,7$, and 14 days of a specific diet with different biotin concentrations. Biotin was used at $0.0,1.8$ or $98.2 \mathrm{mg}$ per $\mathrm{kg}$ of food; and was referred to as biotin deficient, sufficient and supplemented, respectively. Water and food supply and consumption by the three groups of mice were the same. Therefore, the observed effects were directly related to biotin ingestion. The body weight of biotin supplemented mice was the same as the body weight of mice in the biotin sufficient group, while biotin deficiency caused body weight reduction after 7 days of biotin depletion. We found that the total protein concentration in the vastus lateralis muscle is associated with the biotin content in the diet. After $\mathbf{7}$ days, the muscle total protein content was lower in mice of the biotin deficient

\footnotetext{
${ }^{*}$ This work was supported by a grant from the Dirección General de Asuntos del Personal Académico (DGAPA), Universidad Nacional Autónoma de México (PAPIIT IN215311). MA P MdeO was fellow of DGAPA.

${ }^{\#}$ Corresponding author.
}

group while it was higher in the mice from the biotin supplemented group $(P<0.001)$. Of the four analyzed enzymes, only pyruvate carboxylase specific activity was reduced in both cases: by consuming the supplemented diet and by the lack of this vitamin. Our data show that PC and muscle metabolism are differentially altered by both, biotin excess and biotin deficiency. The mechanisms of these effects are currently under investigation.

Keywords: Biotin Deficiency; Biotin Supplementation; Biotin Sufficiency; Skeletal Muscle; Carboxylases; Body Growth

\section{INTRODUCTION}

Biotin or vitamin B7 is a water soluble, essential vitamin in mammals. It acts as a prosthetic group of 5 carboxylase enzymes of the intermediary metabolism of carbohydrates, fatty acids and amino acids. Once synthesized, the apocarboxylases (inactive enzymes) are converted into holocarboxylases by the action of holocarboxylase synthetase. This enzyme covalently binds biotin with a specific lysine at the active site of apocarboxylase [1]. It is proposed that upon reaching its useful life in the cell, holocarboxylases (active enzymes) are degraded into biotinylated peptides or biotin-lysine dimers, which are further hydrolyzed by biotinidase, releasing free biotin that could be reused by the holocarboxylase synthetase [2].

Acetyl CoA carboxylase (ACC) is an enzyme that catalyzes the carboxylation of acetyl-CoA to form malonylCoA. There are two forms of this enzyme: ACC1 and ACC2. The ACC1 isoform is expressed mainly in the 
cytosol of cells from lipogenic tissues such as liver, adipose tissue and mammary gland [3]. This malonyl-CoA is intended to synthesize fatty acids by donating $\mathrm{C} 2$ units for the elongation process [4]. ACC2 is primarily found in heart and skeletal muscle, where it is associated with the external mitochondrial membrane [5]. This enzyme also produces malonyl-CoA. By its location, ACC2 is associated with and inhibits carnitine palmitoyl transferase $\mathrm{I}$, thus preventing the regulation of $\beta$-oxidation [6].

$\beta$-methylcrotonyl-CoA carboxylase (MCC) is located in the mitochondrial matrix and catalyzes the carboxylation reaction of 3-methylcrotonyl-CoA to form 3 methylglutaconyl-CoA, which is an intermediate product in leucine catabolism [7]. Propionyl-CoA carboxylase (PCC) acts on propionyl-CoA to form methylmalonyl-CoA, a substance involved in the $\beta$-oxidation of the odd-chain fatty acids. PCC also participates in isoleucine, valine, threonine and methionine catabolism [8]. Pyruvate carboxylase (PC) is the enzyme responsible for catalyzing the reaction of pyruvate to oxaloacetate. Oxaloacetate is the first reaction substrate for gluconeogenesis, and is also used for Krebs cycle anaplerosis [9,10]. PCC and PC are also located in the mitochondrial matrix.

Congenital errors have been described that contain low carboxylase activity of all or one of these enzymes. Multiple carboxylase deficiency (MCD) is a disease that is characterized by errors in the metabolism of all the biotinylated enzymes and can occur in neonatal or juvenile forms. Clinically these two congenital errors are expressed as a metabolic failure with severe ketoacidosis, accompanied by hyperammonemia, lactic acidosis and hypoglycemia sometimes [11]. The early or neonatal DMC is an autosomal recessive disorder caused by a dysfunction of the holocarboxylase synthetase; and late or juvenile DMC is caused by a genetic disorder that involves the synthesis of inactive biotinidase blocking the availability of free biotin for the formation of holocarboxylases [12].

Biotin deficiency in animal models is induced by a biotin free diet and raw egg white as the sole source of protein $[1,13]$. Egg white contains a tetrameric glycoprotein called avidin capable of sequestering biotin in a $1: 4$ ratio $[1,14]$. The avidin biotin complex is not degraded by the enzymes of the digestive tract in mammals, producing the vitamin deficiency $[13,15]$. The specific activity of carboxylases in the liver is the best biochemical indicator of the nutritional status of biotin. Liver is the organ with highest carboxylases concentration. In biotindeficient mice, liver PCC and PC activities decrease by $80 \%$ [13]. In rat skeletal muscle [16,17] and human muscle [18] it has been shown that the specific activity of ACC decreases progressively due to muscle contraction and in response to exercise intensity [16]. This reduction in activity is due to the phosphorylation of ACC, which holds priority, and is independent of the activation of this enzyme by citrate [17].

It has been shown that biotin deficiency reduces body weight in all animal models so far studied [1], and that this loss is mostly at the expense of muscular mass [13, 19]. When necessary, the liver uses skeletal muscle protein to provide glucose and amino acids to the brain and the immune system components [20]. Since carboxylases play an important role in intermediate metabolism, in this study we followed the carboxylases specific activity through time in the vastus lateralis muscle of mice fed for two weeks with diets containing different biotin concentrations.

\section{MATERIALS AND METHODS}

\subsection{Murine Experimental Model}

The procedure that was performed is the same as the one established previously $[13,19,21]$. We used 39 three weeks old male mice of BALB/c strain obtained from the animal facility of the Instituto de Investigaciones Biomédicas (IBB) of the Universidad Nacional Autónoma de México. Mice were maintained with microbiological barriers in 12-hour cycles of light and dark, and water and food were provided ad libitum. All animals were handled according to the guidelines of the Internal Committee for the Care and Use of Laboratory Animals of the IIB (www.biomedicas.unam.mx). Upon receipt, mice were accommodated into three groups so that their average body weight and dispersion were equal.

Each group was given one of the following diets:

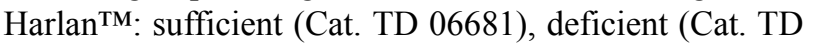
06682) or supplemented (TD 96075) containing 1.8, 0.0 and $98.2 \mathrm{mg}$ of biotin available per $\mathrm{kg}$ of food (control, deplete, and pharmacologic dose, respectively). With the exception of biotin, all other ingredients were the same, including the $30 \%$ of solids from dry egg white as the sole source of protein. The detailed composition of the diets was published previously [21]. At 1, 4, 7 and 14 days of the experiment, specific carboxylase activities were measured in the skeletal muscle of 3 mice from each group. To determine the initial parameters of the batch, three mice were sacrificed at the time of receipt (time 0).

\subsection{Food and Water Consumption}

Registration of food and water consumption was performed 3 times per week and the specific consumption $\left(C_{s}\right)$ of food or water calculations were performed using the following formulas:

$$
C_{d}=\frac{\left(A_{i}-A_{f}\right)}{n * d} ; C_{s}=\frac{C_{d}}{P}
$$

where $C_{d}$ is the consumption per mouse per day, $A_{i}$ is the offered food or water, $A_{f}$ is the remaining food or water, 
$n$ is the number of mice per group, $\mathrm{d}$ are the days elapsed and $P$ is the average weight of the mice in the group.

\subsection{Obtaining Skeletal Muscle}

The day of the experiment, each mouse was sacrificed by cervical dislocation. The vastus lateralis muscle of each hind limb was dissected according to Walker and Homberger, 1997 [22]; they were immediately frozen in liquid nitrogen and then stored at $-80^{\circ} \mathrm{C}$ until analysis.

\subsection{Muscle Homogenization}

The whole procedure was made in an ice bath. With PRO 200 homogenizer set at intensity 3 , the muscle was homogenized $(1: 4 \mathrm{w} / \mathrm{v})$ in a solution containing $290 \mathrm{mM}$ sucrose, $11.57 \mathrm{mM}$ tricine, $0.058 \mathrm{mM}$ disodium EDTA and $5.78 \mathrm{mM}$ sodium citrate at $\mathrm{pH} 7.5$. Four sessions of 30 seconds each were conducted with 1 minute rest in between. An aliquot of the homogenate was diluted 1:6 with lysis buffer $(50 \mathrm{mM}$ tricine and $0.025 \mathrm{mM}$ disodium EDTA pH 8.0) to disrupt the cells with Ultrasonic Processor GE130PB using 3 sets of 30 pulses at $60 \mathrm{MHz}$ for 0.5 seconds, sandwiching 1 minute rest between each set.

Tissue suspension was centrifuged in an Eppendorf 5415R centrifuge at $12,000 \mathrm{rpm}$ for 1 minute at $4^{\circ} \mathrm{C}$ and the supernatant was recovered to measure the carboxylase activity. Protein concentration in this preparation was determined in triplicate with the reagent from BioRad cat. 43622A using the method of Bradford [23], adapting to 96-well microplates in which the absorbance was measured at $595 \mathrm{~nm}$ with a Biotek EL808 reader.

\subsection{Radioenzymatic Assay}

Immediately after preparing the skeletal muscle homogenate, carboxylases specific activities were quantified using the radioenzymatic method previously described for liver and spleen [13] and for thymocytes [21]. This procedure uses $\mathrm{NaH}^{14} \mathrm{CO}_{3}$ as substrate that forms ${ }^{14} \mathrm{C}$ radioactive products that are quantified by a liquid scintillation counter. For determining the MCC, $10 \mu \mathrm{L}$ of the homogenate was mixed with $10 \mu \mathrm{L}$ of a reaction mixture that resulted in a basis incubation solution that contained $10 \mathrm{mM} \mathrm{NaH}{ }^{14} \mathrm{CO}_{3}$ (15.53 DPM/pmol), $100 \mathrm{mM}$ tricine, $6 \mathrm{mM}$ magnesium acetate, $50 \mathrm{mM}$ potassium acetate, 3.3 $\mathrm{mM}$ ATP, $2.5 \mathrm{mM}$ reduced glutathione, $\mathrm{pH} 8.0$, plus 2.4 $\mathrm{mM} \beta$-methylcrotonyl CoA, final concentration. For measuring the PCC activity the coenzyme used was $2.4 \mathrm{mM}$ Propionyl CoA. For the ACC activity analysis, the reaction mixture contained the basis incubation solution plus $0.245 \mathrm{mM}$ acetyl CoA, $10 \mathrm{mM}$ citric acid and bovin serum albumin (final incubation concentration $93.75 \mathrm{mg}$ / L). For PC activity determination, the mixture based reaction contained $0.9 \mathrm{mM}$ acetyl CoA, citrate synthase and pyruvic acid (final incubation concentration of 23.25 $\mathrm{U} / \mathrm{mL}$ and $4.5 \mathrm{mM}$, respectively). Reaction blanks for each enzyme were prepared identically without their corresponding coenzyme.

ACC reactions were incubated for $3 \mathrm{~min}$ at $37^{\circ} \mathrm{C}$, the MCC ones for $3 \mathrm{~min}$ at $30^{\circ} \mathrm{C}$ and the $\mathrm{PCC}$ and $\mathrm{PC}$ for 10 $\min$ at $30^{\circ} \mathrm{C}$. At the end of the incubation period, all the reactions tubes were vertically set in an ice bath and then placed in a fume hood of air in order to add $20 \mu \mathrm{L}$ of $30 \%$ formic acid. The resulting $40 \mu \mathrm{L}$ was transferred to scintillation vials and each tube was washed with another $40 \mu \mathrm{L}$ of $30 \%$ formic acid (which were added to the corresponding scintillation vial). The reaction products in the vials were evaporated to dryness in a fume hood of air for 15 hours, and then resuspended in $0.5 \mathrm{~mL}$ of milliQ water and $2.5 \mathrm{~mL}$ of OptiPhase HiSafe 3 scintillation fluid (Perkin Elmer 1200 - 437). The radioactivity of the samples was measured in a Beckman scintillation counter LS 6500.

To calculate the specific activity of the enzymes, the following formula was used:

$$
\text { Specific Activity }=\frac{\mathrm{DPM}_{\text {net }}\left(\frac{1000}{\text { bicarbonate activity }}\right)}{\min _{\text {incub. }}(\mu \mathrm{g} \text { protein })}
$$

\subsection{Statistical Analysis}

Data were analyzed with the 2 way ANOVA test using the Sigma Stat 3.10 software and they were considered statistically significant when $\mathrm{P} \leq 0.05$. Post hoc testing conducted for protein concentration in skeletal muscle was Bonferroni and Tukey for body weight and specific activities of carboxylases, respectively.

\section{RESULTS}

\subsection{Body Weight}

The body weight gain in the deficient mice group was lower from day 7 of study, while consumption of pharmacologic doses of biotin did not affect this parameter (Figure 1). It was observed the characteristic effect of biotin deficiency on decrease body growth $[13,19,21,24]$, while no modification of this parameter in biotin supplemented mice, as compared with sufficient group. The last results coincide with previous reports [24].

\subsection{Food and Water Consumption}

The quantity of ingested food and water was not affected by the presence of biotin in the food. The specific consumption of water and food during the 2 weeks of the experiment was calculated according to the formulas presented in Section 2.2 and data is shown in Table 1. It should be noted that due to experimental design, a single 
data is documented per hosted group session in a box, so the average value of all data recorded during the study is presented. The food intake trend for this work is similar to that of previous reports $[19,24]$. With regards to water consumption, this is the first report.

Based on measured food consumption and the biotin content available in each of the diets [24], the amount of vitamin intake was calculated. Mice in the sufficient group consumed $0.005 \pm 0.001 \mathrm{mg}$ of biotin/day ${ }^{*}$ mouse; and in the supplemented group $0.247 \pm 0.034 \mathrm{mg}$ of biotin/day ${ }^{*}$ mouse. Values correspond to the ratio of the biotin content in each diet (1:49).

\subsection{Total Protein Concentration in Skeletal Muscle}

The total protein concentration in the vastus lateralis muscle is associated with the biotin content in the food. After 7 days, the total protein content was lower in the vastuslateralis muscle of biotin deficient mice, whereas in the vitamin-supplemented mice it was higher (Figure 2, $\mathrm{P}<$ $0.001)$.

\subsection{Specific Activity of the Carboxylases}

The range of carboxylases specific activity in the skeletal muscle of mice of the sufficient group is shown in Table 2. These values were consistent with those reported for rat skeletal muscle, where the specific activity of the ACC was $0.38 \pm 0.06 \mathrm{nmol}{ }^{14} \mathrm{CO}_{2}$ fixed $/ \mathrm{min}{ }^{*} \mathrm{mg}$ protein [17] whereas those of PCC and PC were of $13.1 \pm 5.0$ and $3.4 \pm 1.9 \mathrm{nmol}{ }^{14} \mathrm{CO}_{2}$ fixed $/ \mathrm{min}{ }^{*} \mathrm{mg}$ protein (mean \pm

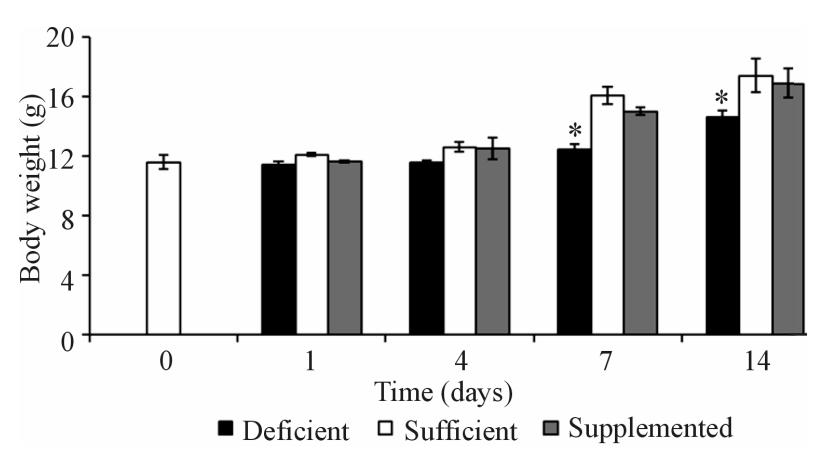

Figure 1. Body weight of mice of the 3 experimental groups. Values are expressed as mean \pm SEM. ${ }^{*} \mathrm{P}<0.001$ deficient vs. sufficientand supplemented.

Table 1. Food and water consumption along 2 weeks of study (mean $\pm \mathrm{SEM}$ ).

\begin{tabular}{ccc}
\hline & Diet (g/day ${ }^{*}$ mouse) & Water (mL/day ${ }^{*}$ mouse) \\
\hline Deficient & $2.48 \pm 0.51$ & $3.88 \pm 1.16$ \\
Sufficient & $2.86 \pm 0.65$ & $5.51 \pm 0.78$ \\
Supplemented & $2.37 \pm 0.34$ & $6.37 \pm 0.87$ \\
\hline
\end{tabular}

SEM), respectively [25]. It is noteworthy that to our knowledge, this is the first study that measures the MCC activity in skeletal muscle.

Of the four enzymes analyzed in vastus lateralis mice muscle, only PC specific activity was reduced under both biotin conditions: the use of pharmacological doses of biotin, and the biotin depleting diet (Figure 3(d)). After 4 days of experimentation, the deficient and supplemented groups showed smaller PC activity than mice fed with the sufficient diet. At 14 days it was recovered in the supplemented group, while in the deficient group it got more exacerbated $(\mathrm{P}<0.001)$. The time course of the enzymatic activities of ACC, MCC and PCC, although not significant, showed the same trend from day 7 (Figures 3(a)-(c)).

\section{DISCUSSION}

The study described herein addresses for the first time the analysis of the four biotinylated enzymes that are active in the intermediary metabolism in skeletal muscle. Furthermore, it examines the response of these carboxylases to food consumption that contains different concentrations of biotin.

Because the specific consumption of water and food was the same in the three experimental groups, all results presented in this paper were caused exclusively by the amount of biotin ingested. This vitamin was the only ingredient in the three diets, present at varying concentrations; macro and micronutrient concentrations were not changed.

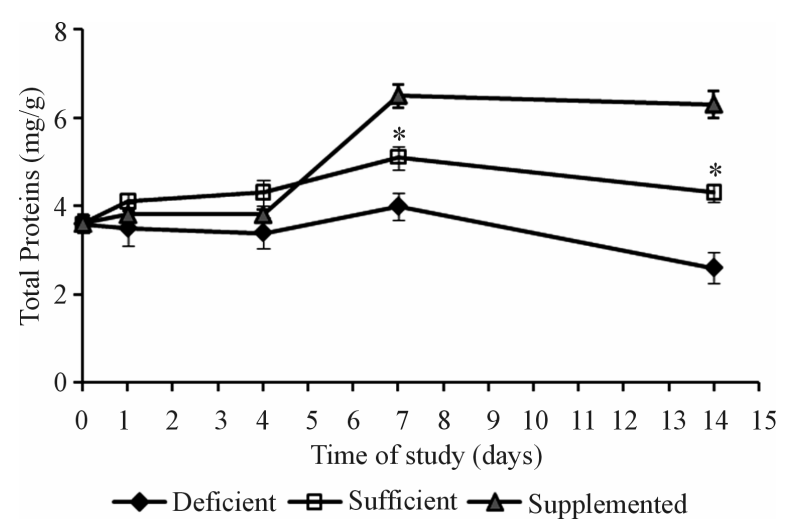

Figure 2. Total protein content in the squeletal muscle (mean \pm SEM). ${ }^{*} \mathrm{P}<0.001$ sufficient vs. deficient and supplemented.

Table 2. Specific activities range of carboxylases acting on the vastus lateralis muscle of mice fed during 2 weeks with biotin sufficient diet.

\begin{tabular}{cccc}
\hline \multicolumn{4}{c}{ Sufficient Group $\left({ }^{14} \mathrm{CO}_{2}\right.$ nmol fixed $/ \mathrm{min}^{*}{ }^{*} \mathrm{mg}$ protein $)$} \\
\hline ACC & MCC & PCC & PC \\
$0.2-0.4$ & $1.1-2.2$ & $2.8-6.3$ & $2.0-7.7$ \\
\hline
\end{tabular}




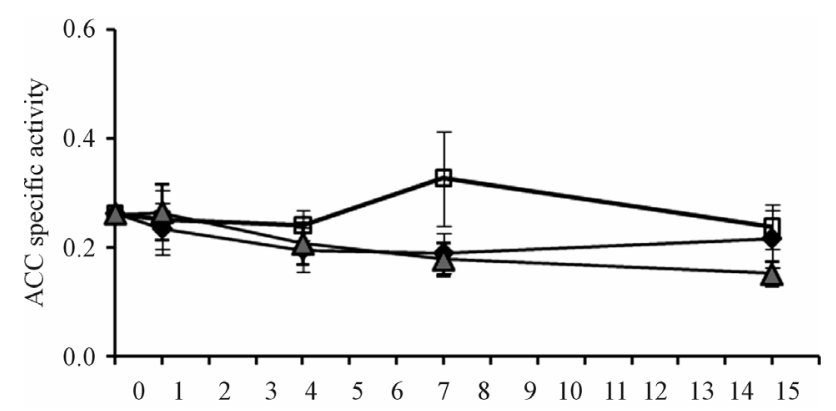

(a)

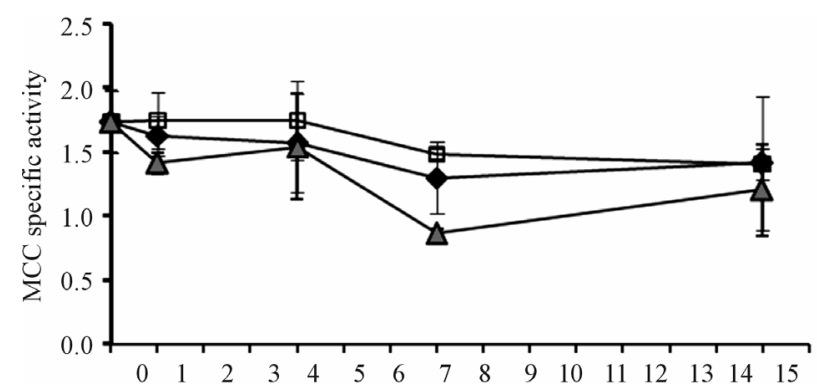

(b)

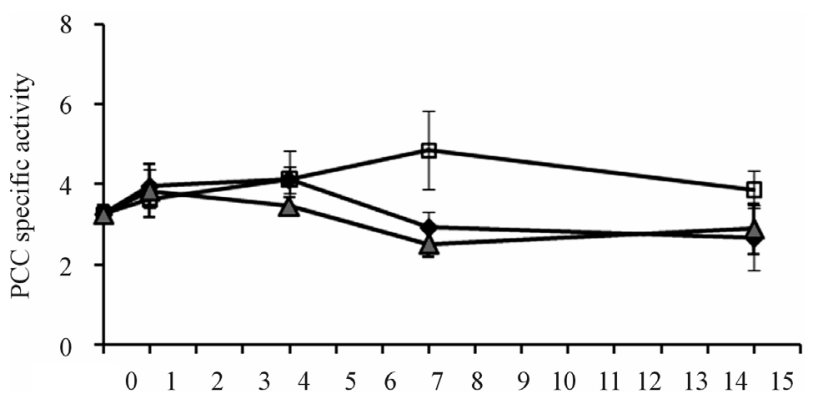

(c)

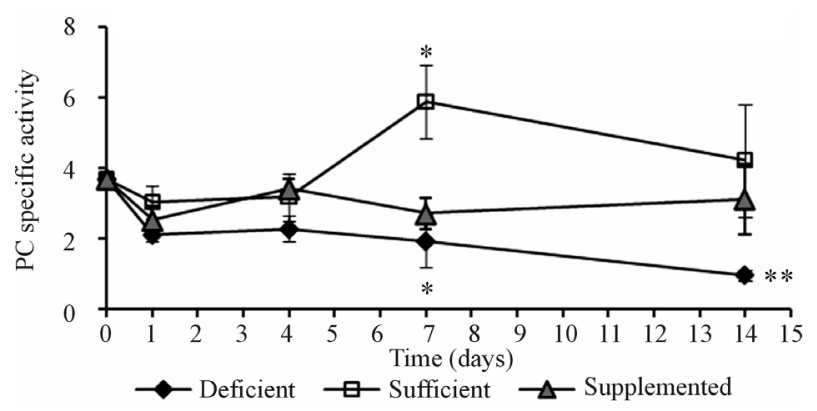

(d)

Figure 3. Specific activities of carboxylases $\left({ }^{14} \mathrm{CO}_{2} \mathrm{nmol}\right.$ fixed $/ \mathrm{min}$ "mg prot) in mice skeletal muscle. (a) Acetyl-CoA carboxylase; (b) Methylcrotonyl-CoA carboxylase; (c) Propionyl-CoA carboxylase; (d) Pyruvate carboxylase. ${ }^{*} \mathrm{P}<0.05$ sufficient vs. deficientand supplemented. ${ }^{* *} \mathrm{P}<0.05$ deficient vs. sufficient and supplemented (mean \pm SEM).

Skeletal muscle is the most abundant tissue in the body and one of the most important places in which the metabolic activity of an individual takes place. It constitutes almost $50 \%$ of total body weight and contains between $50 \%$ and $75 \%$ of total protein [26]. These proteins upon catabolism are a large source of amino acids for energy production as well as fuel to critical organs such as the liver, which in turn, provides energy and maintains acute phase proteins synthesis to the brain, heart, lung and immune system cells [27].

The results presented for the group fed with the sufficient diet corroborate that this composition covers all requirements for the proper development and metabolism of mice $[13,19,21,24]$. Thus, it can be said, that the activities of carboxylases in the skeletal muscle of the sufficient group shown in this study, can serve as a reference for normal conditions and intakes, especially for mitochondrial carboxylases. It should be noted that these enzymes haven't been studied extensively in skeletal muscle so far, despite the high content of mitochondria in this tissue. It is within mitochondria where MCC, PCC and $\mathrm{PC}$ reactions take place.

Among carboxylases, the cytoplasmic enzyme ACC1 in skeletal muscle is the one that has been mostly studied [16-18]. ACC activity was not altered by the amount of biotin ingested, indicating that the fatty acid metabolism is neither affected during two weeks of consumption of deficient, sufficient or supplemented diets. By molecular biology methods, the two ACC isoforms (ACC1 and ACC2) have been identified in skeletal muscle, being ACC2 the predominant one in this tissue [4,28]. Other studies that have measured the ACC activity in this tissue report the sum of the two isoenzymes [16-18]. There was no separation of the two isoforms in our study either.

The PCC reactions that enable the use of odd-chain fatty acids and branched chain amino acids for the production of both glucose and energy [29] were not affected by the lack or excess of biotin in the diet for a 2 week period. In these groups, the PCC specific activity values were similar to the muscle in biotin sufficient mice.

Several studies have shown that protein synthesis in skeletal muscle is regulated by leucine and insulin [30-33] and it is this tissue the one that mostly degrades the leucine $[34,35]$. The procedure applied in this work did not affect the activity of MCC suggesting that leucine metabolism is not affected. Therefore the increase in protein muscle concentration by the supplemented group, may be caused by the action of biotin on insulin production, since it has been observed that biotin stimulates the release of insulin [36-38].

The poor weight gain by biotin deficient mice is characteristic of this condition and occurs mainly at the expense of muscle mass $[13,19,21,24]$. It is worth noting that it is associated with a reduction in the total muscle protein concentration (this study). These results may be due to an inhibition of protein synthesis and/or an increase in protein degradation. Therefore studies to elucidate between these possibilities are required. Although 
the total protein concentration is nonspecific, it is used to calculate the specific activities of the carboxylases. Considering the magnitude of these ratios (mg protein/g muscle vs. $\mathrm{nmol}^{14} \mathrm{CO}_{2}$ fixed $/ \mathrm{min}{ }^{*} \mathrm{mg}$ protein) and the fact that only PC activity is altered by excess or deficiency of biotin consumption, we propose two possible mechanisms to explain the poor gain weight: a) disturbance of PC metabolism and b) a non-prosthetic and direct action of biotin. It has been shown that biotin deficiency reduces the levels of IGF-I in serum [19]. This factor is known to induce cell proliferation in skeletal muscle [39]. It is possible as well that biotin deficiency also decreases the IGF-I metabolism in the muscle, explaining the effect on the body weight and the amount of protein in the muscle of the deficient mice.

In recent years it has been considered that supplementation with pharmacological doses of biotin also leads to endocrine, systemic, and metabolic actions [24,40-41]. To our knowledge, there are no reports exploring the effect of biotin on vastus lateralis muscle carboxylases. Here we demonstrate that supplementation with biotin specifically alters PC activity in skeletal muscle and increases the total protein concentration in this tissue without affecting body mass. Since it is known that PC activity is reduced in the liver in biotin deficient mice [13], it was expected the same effect in skeletal muscle, but not in the supplemented group. Our results indicate that pharmacological doses of biotin produce an energy metabolism alteration. Under normal conditions, the presence of PC in skeletal muscle is related to the Krebs cycle anaplerosis $[10,25]$. In this tissue, there is truly a constant input and output of tricarboxylic acid cycle intermediaries, which accumulate in metabolic conditions such as diabetes. The lower activity of PC in supplemented mice can explain the hypoglycemic effect that the pharmacological treatment of biotin has in diabetic patients [41, 42].

Our data shows that lack or excess of biotin in the diet can alter both, PC metabolism and general muscle metabolism. At this time, other experiments are being developed to elucidate the mechanisms of these effects.

\section{ACKNOWLEDGEMENTS}

We thank to Georgina Díaz H. and Jorge García R. for their expert assistance on care of the mice. We thank Nancy Mora P. and Jesús Ramírez S. for their excellent technical assistance. Authors are also grateful to Dr. Yolanda Fuchs for helpful criticism and editing.

\section{REFERENCES}

[1] Friedrich, W. (1988) Vitamins. Walter de Gruyter.

[2] Wolf, B. (1995) Disorders in biotin metabolism. In: de Beaudet, A.L., Sly, W.S., Valle, D. and Scriver, C.R., Eds., The Metabolic and Molecular Bases of Inherited
Disease. McGraw Hill, New York, 3151-3177.

[3] Bianchi, A., Evans, J.L., Iverson, A.J., Norlund, A.C., Watts, T.D. and Witters, L.A. (1990) Identification of an isozymic form of acetyl-CoA carboxylase. The Journal of Biological Chemistry, 25, 1502-1509.

[4] Abu-Elheiga, L., Almarza-Ortega, D.B., Baldini, A. and Wakil, S.J. (1997) Human acetyl-CoA carboxylase 2. The Journal of Biological Chemistry, 272, 10669-10677.

[5] Abu-Elheiga, L., Brinkley, W.R., Zhong, L., Chirala, S.S., Woldegiorgis, G. and Wakil, S.J (2000). The subcellular localization of acetyl-CoA carboxylase 2. Proceedings of the National Academy of Sciences, 97, 1444-1449. doi:10.1073/pnas.97.4.1444

[6] Power G.W. and Newsholme E.A. (1997) Dietary fatty acids influence the activity and metabolic control of mitochondrial carnitine palmitoyltransferase $\mathrm{I}$ in rat heart and skeletal muscle. Journal of Nutrition, 127, 21422150.

[7] Baumgartner, M.R., Almashanu, S., Sourmala, T., Obie, C., Cole, R.N., Packman, S., Baumgartner, E.R. and Valle, D. (2001). The molecular basis of human 3-methyl-crotonyl-CoA carboxylase deficiency. Journal of Clinical Investigation, 107, 495-504. doi:10.1172/JCI11948

[8] Browner, M.F., Taroni, F., Sztul, E. and Rosenberg, L.E. (1989) Sequence analysis, biogenesis and mitochondrial import of the alpha-subunit of rat liver propionyl CoA carboxylase. The Journal of Biological Chemistry, 284, 12680-12685.

[9] Utter, M.F. and Keech, D.B. (1963) Pyruvate carboxylase I Nature of the reaction. The Journal of Biological Chemistry, 238, 2603-2608.

[10] Jitrapakdee, S., Vidal-Puig, A. and Wallace, J.C. (2005) Anaplerotic roles of pyruvate carboxylase in mammalian tissues (Review). Cellular and Molecular Life Science, 63, 843-854. doi:10.1007/s00018-005-5410-y

[11] Hernández, R.M. (2001) Alimentación infantil. Díaz de Santos, España

[12] Ortega Anta, R.M. and Requejo Marcos, A.M. (2003) Nutriguía: Manual de nutrición clínica en atención primaria. Complutense.

[13] Báez-Saldaña, A., Díaz, G., Espinoza, B. and Ortega, E. (1998) Biotin deficiency induces changes in subpopulations of spleen lymphocytes in mice. American Journal of Clinical Nutrition, 67, 431-437.

[14] Green, N.M. (1975) Avidin. Advances in protein chemistry, 29, 85-133. doi:10.1016/S0065-3233(08)60411-8

[15] Melo Ruíz, V. and Cuamatzi, O. (2007) Bioquímica de los procesos metabólicos. 2nd Edition, Reverte.

[16] Rasmussen, B.B. and Winder, W.W. (1997) Effect of exercise intensity on skeletal muscle malonyl-CoA and acetyl-CoA carboxylase. Journal of Applied Physiology, 83, 1104-1109.

[17] Vavvas, D., Apazidis, A., Saha, A.K., Gamble, J., Patel, A., Kemp, B.E., Witters, L.A. and Ruderman, N.B. (1997) Contraction-induced changes in acetyl CoA carboxylase and 5'-AMP-activated kinase in skeletal muscle. Journal 
of Biological Chemistry, 272, 13255-13261. doi:10.1074/jbc.272.20.13255

[18] Dean, D., Daugaard, J.R., Young, M.E., Saha, A., Vavvas, D., Asp, S., Kiens, B., Kim, K., Witters, L., Richter, E.A. and Ruderman, N. (2000) Exersice diminishes the activity of acetyl CoA carboxylase in human muscle. Diabetes, 49, 1295-1300. doi:10.2337/diabetes.49.8.1295

[19] Báez-Saldaña, A., Gutierrez-Ospina, G., Chimal-Monroy, J., Fernández-Mejía, C. and Saavedra, R. (2009) Biotin deficiency in mice is associated with decreased serum availability of insulin-like growth factor-I. European Journal of Nutrition, 48, 137-144. doi:10.1007/s00394-009-0773-8

[20] Styer, L. (1995) Bioquímica. 4th Edition, Reverte.

[21] Báez-Saldaña, A. and Ortega, E. (2004) Biotin deficiency blocks thymocyte maturation, accelerates thymus involution, and decreases nose-rump length in mice. Journal of Nutrition, 134, 1970-1977.

[22] Walker, W.F. and Homberger, D.G. (1997) Anatomy and dissection of the rat. W. H. Freeman \& Company.

[23] Bradford, M.M. (1976) A rapid and sensitive method for the quantitation of microgram quantities of protein utilizing the principle of protein dye binding. Analytical Biochemistry, 72, 248-254. doi:10.1016/0003-2697(76)90527-3

[24] Báez-Saldaña, A., Camacho-Arroyo, I., Espinosa-Aguirre, J.J., Neri-Gómez, T., Rojas-Ochoa, A., Guerra-Araiza, C., Larrieta, E., Vital, P., Díaz, G., Chavira, R. and Fernández-Mejía, C. (2009) Biotin deficiency and biotin excess: Effects on the female reproductive system. Steroids, 79, 863-869.

[25] Davis, E.J., Spydevold, O. and Bremer, J. (1980) Pyruvate carboxylase and propionyl CoA carboxylase as anaplerotic enzymes in skeletal muscle mitochondria. European Journal of Biochemistry, 110, 225-262. doi:10.1111/j.1432-1033.1980.tb04863.x

[26] Salter, R.B. (2000) Trastornos y lesionesdelsistemamúsculoesquelético: Introducción a la ortopedia, fracturas y lesionesarticulares, reumatología, osteopatía metabólica y rehabilitación. Elsevier.

[27] Drummond, J.M., Dreyer, H.C., Fry, C.S., Glynn, E.L. and Rasmussen, B.B. (2009) Nutritional and contractile regulation of human skeletal muscle protein synthesis and mTORC1 signaling. Journal of Applied Physiology, 106, 1374-1384. doi:10.1152/japplphysiol.91397.2008

[28] Castle, J.C., Hara, Y., Raymond, C.K., Garrett-Engele, P., Ohwaki, K., Kan, Z., Kusunoki, J. and Johnson, J.M. (2009) ACC2 is expressed at high levels in human white adipose and has an isoform with a novel N-terminus [corrected]. PLoS One, 4, e4369. doi:10.1371/journal.pone.0004369

[29] Koolman, J. (2005) Bioquímica: Texto y atlas. 3rd Edition, Médica Panamericana.

[30] Hong, S.C. and Layman, D.K. (1984) Effects of leucine on in vitro protein synthesis and degradation in rat mus- cles. Journal of Nutrition, 114, 1204-1212.

[31] Nair, K.S., Schwartz, R.G. and Welle S. (1992) Leucine as a regulator of whole body and skeletal muscle protein metabolism in humans. American Journal of Physiology, 263, E928-E934

[32] Anthony, J.C., Lang, C.H., Crozier, S.J., Anthony ,T.G., MacLean, D.A., Kimball, S.R. and Jefferson, L.S. (2002) Contribution of insulin to the translational control of protein synthesisin skeletal muscle by leucine. Endocrinology and Metabolism: American Journal of Physiology, 282, E1092-E1101.

[33] Norton, L.E. and Layman, D.K. (2006) Leucine regulates translation initiation of protein synthesis in skeletal muscle after exercise. Journal of Nutrition, 136, 533S-537S.

[34] Oddesey, R. and Goldberg, A.I. (1972) Oxidation of leucine by rat skeletal muscle. American Journal of Physiology, 223, 1376-1383.

[35] Hutson, S.M., Cree, T.C. and Harper, A.E. (1978) Regulation of leucine and a-ketoisocaproate metabolism in skeletal muscle. Journal of Biological Chemistry, 253, 8126-8133

[36] Romero-Navarro, G., et al. (1999) Biotin regulation of pancreatic glucokinase and insulin in primary cultured rat islets and in biotin-deficient rats. Endocrinology, 140, 4595-4600. doi:10.1210/en.140.10.4595

[37] Sone, H., Ito, M., Sugiyama, K., Ohneda, M., Maebashi, M. and Furukawa, Y. (1999) Biotin enhances glucosestimulated insulin secretion in the isolated perfused pancreas of the rat. The Journal of Nutritional Biochemistry, 10, 237-243. doi:10.1016/S0955-2863(99)00003-0

[38] Sone, H., Ito, M., Shimizu, M., Sasaki, Y., Komai, M. and Furukawa, Y. (2000) Characteristics of the biotin enhancement of glucose-induced insulin release in pancreatic islets of the rat. Bioscience, Biotechnology, and Biochemistry, 64, 550-554.

[39] Coolican, S.A., Samuel, D.S., Ewton, D.Z., McWade, F.J. and Florini, J.R. (1997) The mitogenic and myogenic actions of insulin-like growth factors utilize distinct signaling pathways. The Journal of Biological Chemistry, 272, 6653-6662. doi:10.1074/jbc.272.10.6653

[40] Fernandez-Mejia, C. (2005) Pharmacological effects of biotin. The Journal of Nutritional Biochemistry, 16, 424427. doi:10.1016/j.jnutbio.2005.03.018

[41] Aguilera-Méndez, A. and Fernández-Mejía, C. (2012) The hypotriglyceridemic effect of biotin supplementation involves increased levels of cGMP and AMPK activation. Biofactors, 38, 387-94. doi:10.1002/biof.1034

[42] Revilla-Monsalve, C., Zendejas-Ruiz, I., Islas-Andrade, S., Báez-Saldaña, A., Palomino-Garibay, M.A., Hernández-Quiróz, P.M. and Fernandez-Mejia, C. (2006) Biotin supplementation reduces plasma triacylglycerol and VLDL in type 2 diabetic patients and in nondiabetic subjects with hypertriglyceridemia. Biomedicine \& Pharmacotherapy, 60, 182-185. 


\section{Appendix}

The abbreviations used are:

ACC, Acetyl-CoA carboxylase;

MCC, Methylcrotonyl-CoA carboxylase;

PCC, Propionyl-CoA carboxylase;

PC, Pyruvate carboxylase. 